\title{
Epidemiology of scleroderma
}

\author{
Alan J Silman
}

\section{Criteria}

There is not a single diagnostic test for scleroderma and until 1980 there were no published criteria. Many would argue, however, that the disease is sufficiently obvious and distinct clinically to obviate the need for specific criteria. A subcommittee of the American Rheumatism Association (ARA) undertook a study of 264 patients with 'definite' scleroderma from 29 centres and compared the clinical findings with those for some $\mathbf{4 0 0}$ patients with either systemic lupus erythematosus, dermatomyositis, polymyositis, or Raynaud's phenomenon. ${ }^{1}$ All patients studied were within two years of onset. The development of criteria was not difficult (table 1), and these criteria were $97 \%$ sensitive and had a specificity of $98 \%$ (99\% compared with the patients with systemic lupus erythematosus and $94 \%$ compared with those with Raynaud's phenomenon). The single criterion of proximal scleroderma was $100 \%$ specific (not surprisingly) and $91 \%$ sensitive. There is a problem here as such a feature is by definition absent from patients with the limited cutaneous form of the disease and thus the criteria are likely to be insensitive for that group, who account for about $50 \%$ of patients in published clinical series. Thus in 57 consecutive new patients from New Zealand the ARA criteria were only $79 \%$ sensitive. $^{23}$ By contrast, in a heavily selected group of 47 Belgian patients the criterion of proximal scleroderma was present in all. 4

\section{Occurrence}

Scleroderma is a rare disease and virtually all the descriptive epidemiology is derived from either prospective or retrospective review of patients attending health service institutions serving a defined denominator population.

\section{MORTALITY}

The advantages of using mortality data are that they are readily available for national and other large population groups, and in a disease like scleroderma, with a high and relatively constant patient death rate (there being no treatment proved to improve survival), trends in incidence are reflected in trends in population mortality. The major drawbacks are, of course, the difficulties in standardising diagnosis and completion of death certificates. The overall population mortality in Baltimore (USA) during 1949-63 was $1 \cdot 3$ and $2 \cdot 2$ per million respectively in white men and women. ${ }^{5}$ All subsequent studies have produced similar results. Thus in the USA in
1959-61 the death rates were $1 \cdot 0$ and $2 \cdot 1$ per million respectively ${ }^{6}$ and in 1969-77 were 1.5 and 3.5 per million respectively. ${ }^{7}$ Data from American male veterans for 1963-68 were also similar at 1.4 per million. ${ }^{8}$ Recent data from the United Kingdom for 1974-85 are also similar with rates of 1 and 4 per million respectively. ${ }^{9}$ Figure 1 shows the age specific population mortality curves for both the USA and the United Kingdom, illustrating the rarity of the disease under the age of 25 and the relatively slow increase in mortality with increasing age until the seventh decade. These data therefore suggest that scleroderma is a disease with a relatively stable occurrence (at least as judged by mortality) both over time and between populations.

\section{INCIDENCE}

There have been 10 published reports of scleroderma incidence (table 2). The published incidences vary between 2 and 10 per million, though the most recent data from the Pittsburgh group suggest an even higher incidence. ${ }^{10}$ The incidences, however, are relatively consistent between the different countries according to the available data. The Mayo Clinic studies ${ }^{11} 12$ have the advantage that the nature of the health care system is such that all patients within their denominator population are likely to be ascertained. This population is small, however, and the confidence intervals are wide-for example, men $0-6$ per million, women $7-25$ per million. ${ }^{12}$

\section{Age, sex, and time trends}

All studies show a female excess (table 2) varying from $3: 1$ to $8: 1$. This female excess is more marked in early adult life ${ }^{1314}$ at about 7:1, with the excess narrowing to $2-3: 1$ in the fifth and subsequent decades. The age specific incidence histogram (fig 2) shows the rarity of the disease under the age of 25 and the peak in incidence in the fifth and sixth decades but the relatively (compared with other diseases) small

Table 1 Classification criteria for scleroderma ${ }^{l}$

\begin{tabular}{ll}
\hline I & $\begin{array}{l}\text { Proximal skin scleroderma } \\
\text { or two of } \\
\text { Sclerodactyly } \\
\text { Digital pitting scars/pulp loss, bibasilar } \\
\text { pulmonary fibrosis }\end{array}$ \\
$\begin{array}{l}\text { Definitions } \\
\text { Skin scleroderma: }\end{array}$ & $\begin{array}{l}\text { Tightness, thickening, and non-pitting } \\
\text { induration excluding local forms of } \\
\text { scleroderma }\end{array}$ \\
Sclerodactyly: & $\begin{array}{l}\text { Scleroderma skin change affecting the } \\
\text { fingers or toes }\end{array}$ \\
Pulp loss: & Loss of substance of digital finger pad \\
\hline
\end{tabular}




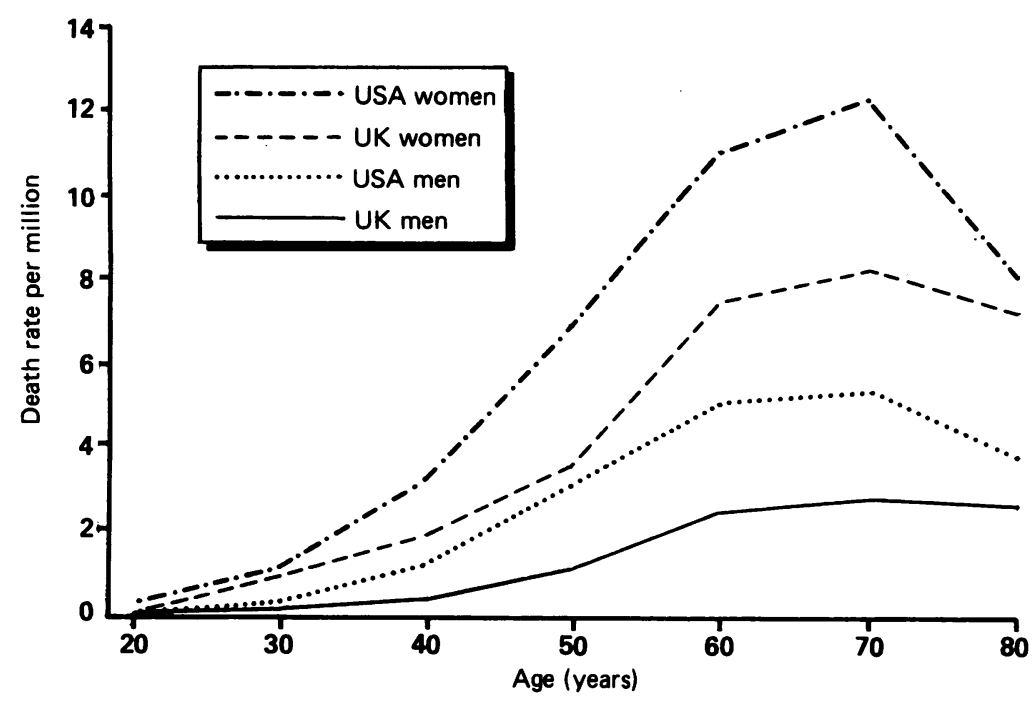

Figure 1 Age specific death rates in the United Kingdom and the United States.

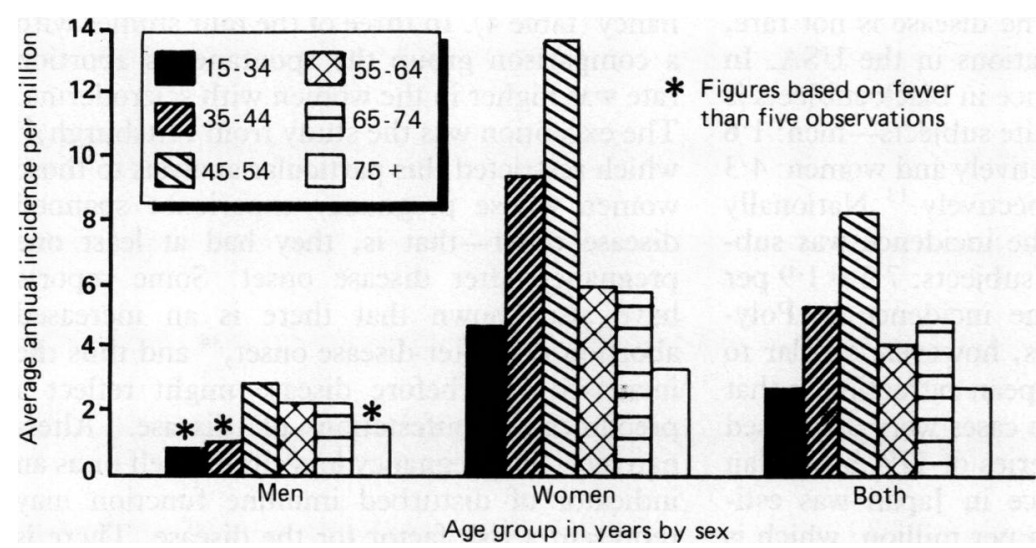

Figure 2 Age specific incidence rates.

Table 2 Incidence studies of scleroderma

\begin{tabular}{|c|c|c|c|c|c|}
\hline \multirow{2}{*}{$\begin{array}{l}\text { Reference } \\
\text { No }\end{array}$} & \multirow[t]{2}{*}{ Country:population } & \multirow[t]{2}{*}{ Period } & \multicolumn{3}{|c|}{ Incidence per million } \\
\hline & & & Men & Women & Both \\
\hline $\begin{array}{l}13 \\
2 \\
11 \\
12 \\
12 \mathrm{a} \\
8 \\
19 \\
24 \\
10 \\
14\end{array}$ & $\begin{array}{l}\text { USA: Tennessee } \\
\text { New Zealand: South Island } \\
\text { USA: Rochester } \\
\text { USA: Rochestert } \\
\text { Czechoslovakia: Piestany } \\
\text { USA: Veterans } \\
\text { USA: Pittsburg } \\
\text { New Zealand: Auckland } \\
\text { USA: Pittsburg‡ } \\
\text { UK: West Midlands }\end{array}$ & $\begin{array}{l}1947-68 \\
1950-73 \\
1951-67 \\
1950-79 \\
1961-69 \\
1963-68 \\
1963-72 \\
1970-79 \\
1963-82 \\
1980-85\end{array}$ & $\begin{array}{l}1 \cdot 2^{*} \\
2 \\
2 \cdot 3\end{array}$ & $\begin{array}{c}20 \cdot 3^{*} \\
6 \cdot 2\end{array}$ & $\begin{array}{c}2 \cdot 7 \\
2 \cdot 3 \\
1 \cdot 2 \\
10 \\
7\end{array}$ \\
\hline
\end{tabular}

*White subjects only.

Includes data from ref 11 .

łIncludes data from ref 19.

Table 3 Prevalence studies of scleroderma

\begin{tabular}{|c|c|c|c|c|c|c|}
\hline \multirow{2}{*}{$\begin{array}{l}\text { Reference } \\
\text { No }\end{array}$} & \multirow[t]{2}{*}{ Country:population } & \multirow{2}{*}{$\begin{array}{l}\text { Source } \\
\text { of data }\end{array}$} & \multirow[t]{2}{*}{ Date } & \multicolumn{3}{|c|}{ Prevalence per million } \\
\hline & & & & Men & Women & Both \\
\hline $\begin{array}{l}11 \\
13\end{array}$ & $\begin{array}{l}\text { USA: Rochester } \\
\text { USA: Tennessee }\end{array}$ & $\begin{array}{l}\text { Mayo Clinic } \\
\text { Multi-institutions }\end{array}$ & $\begin{array}{l}1968 \\
1947-52 \\
1953-57 \\
1958-62 \\
1963-68\end{array}$ & & & $\begin{array}{r}105 \\
4 \\
7 \\
21 \\
28\end{array}$ \\
\hline $\begin{array}{l}12 b \\
12 \\
12 c\end{array}$ & $\begin{array}{l}\text { Denmark } \\
\text { USA: Rochester } \\
\text { East Germany } \\
\text { East Germanv: Leipzig }\end{array}$ & $\begin{array}{l}\text { Multi-hospitals } \\
\text { Mayo Clinic } \\
\text { Two institutions } \\
\text { Two institutions }\end{array}$ & $\begin{array}{l}1977-79 \\
1980 \\
1980-81 \\
1980-81\end{array}$ & 20 & $253 t$ & 126 \\
\hline $\begin{array}{l}14 \\
20\end{array}$ & $\begin{array}{l}\text { East Germany: Leipzig } \\
\text { UK: West Midlands } \\
\text { USA: South Carolina }\end{array}$ & $\begin{array}{l}\text { 1wo instututuons } \\
\text { Multi-institutions } \\
\text { Community survey }\end{array}$ & $\begin{array}{l}1980-81 \\
1986 \\
1988\end{array}$ & $12 \cdot 8$ & $47 \cdot 9$ & $\begin{array}{l}100 \\
30 \cdot 8 \\
290^{*}\end{array}$ \\
\hline
\end{tabular}

${ }^{*}$ Minimum estimate.

†No male cases detected. effect of age. Scleroderma can occur infrequently in childhood ${ }^{15}$ where the CREST (calcinosis, Raynaud's phenomenon, oesophageal dysmotility sclerodactyly, telangiectasia) form is particularly rare. ${ }^{16}$ In contrast, scleroderma is well described in the very elderly (age $80+)^{17}$ and is commonly benign with the CREST form the typical pattern. ${ }^{18}$ This latter observation might reflect the relatively late or missed presentation of those forms of the disease associated with slow progression and high survival. Despite the mortality data showing little variation in incidence over time, in those populations with serial estimates of incidence there has been an increase in occurrence. Thus in Shelby County, Tennessee the incidences (per million) were 0.6 in $1947-52,1.5$ in $1953-57,4 \cdot 1$ in $1958-62$, and 4.5 in $1963-68 .^{13}$ A similar analysis of the period 1963 to 1985 in Allegheny county, Pennsylvania showed the same phenomenon. ${ }^{10}{ }^{19}$ Whether such increases represent a true underlying increase or better ascertainment is unanswered.

\section{PREVALENCE}

Paradoxically, prevalence is a more difficult measure to derive from the available sources, reflecting the lack of cross sectional studies and the requirement to estimate prevalence from retrospective ascertainment of patients alive at a particular date. The difficulties inherent in such an approach are reflected by the wide variation in prevalence shown in table 3. The Mayo Clinic data suffer from the lack of a single male case at 'prevalence day'.12 The data from Tennessee were derived from the incidences. ${ }^{13}$ The United Kingdom data were derived using multiple methods of ascertainment, including primary care and patient self help organisations in addition to hospital clinics. ${ }^{14}$ The most recent survey from South Carolina ${ }^{20}$ was a true community based survey starting with a questionnaire survey for the symptoms of Raynaud's phenomenon in 7000 residents. Only samples of both the positive and negative respondents were followed up, however, and the authors could only derive estimates of prevalence by making a series of assumptions about the occurrence of scleroderma in those not seen. Only two cases were seen, giving a minimum prevalence (subject to a wide confidence interval) of 290 per million. In addition though a further five patients with 'scleroderma spectrum disorders' were detected-that is, patients unable to satisfy the ARA criteria but who had substantive features of scleroderma. The not surprising conclusion from this work is that, as with most other disorders, scleroderma varies in severity, and hospital based epidemiological studies, or indeed studies based on diagnosed cases only, will underestimate the true occurrence of the disease in the community.

GEOGRAPHICAL AND ETHNIC GROUP DISTRIBUTION There does not seem to be any urban/rural difference in occurrence. ${ }^{8}$ Scleroderma has been described in a substantial number of nonWestern populations, including Japan, ${ }^{21}$ USSR 
Table 4 Spontaneous abortion rates before clinical onset of scleroderma

\begin{tabular}{|c|c|c|c|c|c|c|c|}
\hline \multirow{2}{*}{$\begin{array}{l}\text { Reference } \\
\text { No }\end{array}$} & \multicolumn{3}{|l|}{ Cases } & \multicolumn{3}{|l|}{ Controls } & \multirow[t]{2}{*}{ p Value } \\
\hline & $\begin{array}{l}\text { Women } \\
(n)\end{array}$ & $\begin{array}{l}\text { Pregnancies } \\
(n)\end{array}$ & $\begin{array}{l}\text { Spontaneous } \\
\text { abortions }(\%) t\end{array}$ & $\begin{array}{l}\text { Women } \\
(n)\end{array}$ & $\begin{array}{l}\text { Pregnancies } \\
(n)\end{array}$ & $\begin{array}{l}\text { Spontaneous } \\
\text { abortions }(\%) t\end{array}$ & \\
\hline $\begin{array}{l}29 \\
32 \\
31 \\
33 \\
33 a\end{array}$ & $\begin{array}{r}22 \\
86 \\
115 \\
48 \\
28\end{array}$ & $\begin{array}{r}47 \\
299 \\
\\
47 \\
63\end{array}$ & $\begin{array}{l}28 \\
16 \cdot 7 \\
28 \cdot 7^{*} \\
15 \\
33 \ddagger\end{array}$ & $\begin{array}{c}\text { (no con } \\
86 \\
115 \\
48 \S \\
117 \$\end{array}$ & (roup) & $\begin{array}{l}9 \cdot 6 \\
17 \cdot 4^{*} \\
15 \\
15 \ddagger\end{array}$ & $\begin{array}{l}0.01 \| \\
0.04 \\
0.88 \\
0.001\end{array}$ \\
\hline
\end{tabular}

${ }^{*}$ Includes only women who had pregnancy both before and after disease onset.

tPercentage of women.

†All pregnancy losses.

fAll pregnancy losses.
SControls were women with rheumatoid arthritis.

|Difference in rates statistically significant.

(Guseva, unpublished data), Nigeria, ${ }^{22}$ Mexico, ${ }^{23}$ and in Polynesians in New Zealand. ${ }^{24}$ There are, however, few epidemiological data to compare either incidence or prevalence. The Nigerian experience from the limited data provided suggests that scleroderma, if not rare, at least fails to be seen in the main connective tissue disease centre. ${ }^{22}$ The disease is not rare, however, in black populations in the USA. In southern USA the incidence in black subjects is slightly higher than in white subjects-men: 1.6 and $1 \cdot 2$ per million respectively and women: $4 \cdot 3$ and 3.6 per million respectively. ${ }^{13}$ Nationally amongst male veterans the incidence was substantially higher in black subjects: $7 \cdot 1 v 1.9$ per million respectively. ${ }^{8}$ The incidence in Polynesian New Zealanders is, however, similar to that seen in those of European extraction in that country. ${ }^{24}$ In contrast, no cases were diagnosed in Aborigines among a series of 179 Australian patients. ${ }^{25}$ The prevalence in Japan was estimated to be around seven per million, which is substantially lower than that seen in Western countries. 21

Studies within countries have shown some variation in incidence. Thus the American male veterans study showed an increase in incidence after adjustment for race, in those living in the South Atlantic and East South Central (sic) regions of the US, ${ }^{8}$ a phenomenon also found in the national mortality analysis. ${ }^{7}$ In the United Kingdom prevalences in south and west London were higher than those described in the West Midlands. Further analysis of the results for south and west London, according to electoral ward, showed a non-random distribution with a clustering of cases in some small areas. One interesting feature of that study was the apparent concentration in areas adjacent to major international airports. ${ }^{26} \mathrm{~A}$ cluster of patients with a variety of connective tissue diseases was described from Georgia, but formal analysis could not confirm a significant increase in prevalence. $^{27}$

\section{Non-genetic host factors}

There have been few reports of non-genetic host factors and scleroderma and there are no apparent associations with other diseases. The most intriguing line of inquiry has been the reason for the marked female predominance, especially before the menopausal period. In one series the female excess was over 15:1. ${ }^{28}$ There is in fact no difference in the age at menopause of patients with scleroderma compared with the general population. ${ }^{29}$ Patients with scleroderma might have a reduced fertility before disease onset, ${ }^{30} 31$ though others have shown a normal fertility. Of more interest is the possibility that scleroderma is preceded by a higher than normal risk of spontaneous abortion in pregnancy (table 4). In three of the four studies with a comparison group the spontaneous abortion rate was higher in the women with scleroderma. The exception was the study from Pittsburgh, ${ }^{33}$ which restricted this particular analysis to those women whose pregnancy experience spanned disease onset - that is, they had at least one pregnancy after disease onset. Some reports have also shown that there is an increased abortion risk after disease onset, ${ }^{34}$ and thus the increased risk before disease might reflect a preclinical manifestation of disease. Alternatively, the pregnancy loss either itself or as an indicator of disturbed immune function may represent a risk factor for the disease. There is no biological explanation for how such a phenomenon might occur.

\section{Genetics}

Scleroderma is a rare disease as indicated above and thus the random co-occurrence of multiple cases within a family is uncommon. A number of such families have been reported, but it is impossible to determine from such sporadic reports whether there is an excess in first degree relatives of probands. Nonetheless, a considerable number of case reports have emerged over the past 40 years $^{35-45}$ together with many reports in non-English publications. Such reports have limited epidemiological value, and attempts within these families to show linkage with HLA or other genetic markers were either unsuccessful $^{45}$ or inappropriate. There have been a few systematic investigations of large series of probands with scleroderma (table 5). The most obvious conclusion is that the number of such probands with an affected relative is

Table 5 Prevalence of multicase families in probands with scleroderma

\begin{tabular}{lll}
\hline $\begin{array}{l}\text { Reference } \\
\text { No }\end{array}$ & $\begin{array}{l}\text { Number of } \\
\text { probands }\end{array}$ & $\begin{array}{l}\text { Number (\%) } \\
\text { with } \\
\text { affected relative }\end{array}$ \\
\hline 98 & 727 & 0 \\
43 & 154 & $1(0 \cdot 6)$ \\
28 & 164 & 0 \\
61 & 30 & $1(3 \cdot 3)$
\end{tabular}


extremely small and it is unlikely that genetic factors are a major cause of scleroderma. Interestingly, there is a more marked increase in immunological abnormalities in the relatives, such as antinuclear antibody positivity ${ }^{46}$ and evidence of chromosome breakage (a characteristic feature of scleroderma). ${ }^{47}$ The presence of these phenomena might also represent shared environmental exposure, particularly given the increased antinuclear antibody positive rate (24\%) in the 38 spouses of probands with scleroderma. ${ }^{48}$ There have been virtually no reports of scleroderma in twins apart from a single report of concordance for scleroderma in a pair of monozygotic twins. ${ }^{49} \mathrm{~A}$ further pair of disease discordant monozygotic twins were investigated for abnormalities in the immune response. The non-affected twin did not show the immunological abnormalities displayed by the scleroderma co-twin, which led the investigators to conclude that such abnormalities were non-genetic in origin. ${ }^{50}$

\section{IMMUNOGENETICS}

There have been many attempts to demonstrate an association with one or more of the HLA antigens (table 6). Numerous early reports suggested an association with the class I antigen B8, ${ }^{51}$ but this was not a universal finding. ${ }^{53}$ Later testing for class II specificities, particularly $\mathrm{DR}$, suggested an association with DR3 $3^{54}$ and DR5. ${ }^{56-58}$ Further, in Japanese populations DR2 has been associated. ${ }^{59}$ Welsh and Black were able to unify these apparent disparate findings by postulating a role for DRw $52,{ }^{60}$ which is a specificity shared with both DR3 and 5 in Caucasoid populations and with DR2 in

Table 6 HLA associations with scleroderma

\begin{tabular}{|c|c|c|c|c|c|c|c|c|c|c|}
\hline \multirow{2}{*}{$\begin{array}{l}\text { Reference } \\
\text { No }\end{array}$} & \multicolumn{5}{|l|}{ Cases } & \multicolumn{5}{|c|}{ Controls* } \\
\hline & $n$ & $\begin{array}{l}B 8 \\
(\%)\end{array}$ & $\begin{array}{l}D R 1 \\
(\%)\end{array}$ & $\begin{array}{l}D R 3 \\
(\%)\end{array}$ & $\begin{array}{l}\text { DR5 } \\
(\%)\end{array}$ & $n$ & $\begin{array}{l}B 8 \\
(\%)\end{array}$ & $\begin{array}{l}D R 1 \\
(\%)\end{array}$ & $\begin{array}{l}D R 3 \\
(\%)\end{array}$ & $\begin{array}{l}\text { DR5 } \\
(\%)\end{array}$ \\
\hline \multirow{5}{*}{$\begin{array}{l}52 \\
53 \\
62 \\
57 \\
58 \\
51 \\
59 a\end{array}$} & $\begin{array}{r}52 \\
106\end{array}$ & $\begin{array}{l}40 \\
25\end{array}$ & & & & $\begin{array}{r}3000 \\
208\end{array}$ & $\begin{array}{l}29 \\
17\end{array}$ & & & \\
\hline & 125 & & 22 & 25 & 33 & 95 & & 12 & 22 & 31 \\
\hline & $\begin{array}{l}50 \\
46\end{array}$ & 32 & $\begin{array}{l}20 \\
22\end{array}$ & $\begin{array}{l}36 \\
35\end{array}$ & $\begin{array}{l}30 \\
26\end{array}$ & $\begin{array}{l}195 \\
201\end{array}$ & 22 & $\begin{array}{l}15 \\
19\end{array}$ & $\begin{array}{l}28 \\
30\end{array}$ & $\begin{array}{l}15 \\
17\end{array}$ \\
\hline & 54 & 33 & & & & 104 & 19 & & & \\
\hline & $35 t$ & & 31 & 37 & 31 & 1094 & & 18 & 24 & 18 \\
\hline
\end{tabular}

${ }^{*}$ Large numbers, often from large blood donor panels.

tWhite patients only.

Table 7 Environmental agents implicated in scleroderma

Silica dust: coal miners, gold miners, stonemasons

Organic chemicals

(a) Aromatic hydrocarbons: toluene, benzene, xylene, aromatic mixes: white spirit, dieselene (b) Aliphatic hydrocarbons:

(i) Chlorinated: vinyl chloride, trichloroethylene, perchloroethylene

(ii) Non-chlorinated: naphtha-n-hexane

Toxic oil

Epoxy resins

Biogenic amines: $m$-phenylenediamine

Urea formaldehyde foam insulation

Drugs: bleomycin, carbidopa, L-5-hydroxytryptophan, pentazocine, cocaine, appetite suppressants-eg, diethylpropion, fenfluramine hydrochloride

Breast augmentation: silicone, paraffin
Japanese populations (DR3 is itself in common association (linkage disequilibrium) with B8). There have also been frequent attempts to link specific clinical and serological subgroups of scleroderma with specific HLA antigens. Thus B8 is more prevalent in those with systemic disease, ${ }^{52}$ whereas there are conflicting reports of the association with DR5. Two studies showed a significant excess of DR5 in the CREST form, ${ }^{5761}$ whereas the opposite was found in an Australian study, ${ }^{58}$ the control prevalence for DR5 in the studies being similar. One further study with an unusually high background prevalence of DR5 showed no increase with any subgroup of the disease. ${ }^{62}$ Serological subgroups have proved more robust. Thus two reports have shown a higher rate of DR5 in those with the Scl-70 antibody, ${ }^{63}$ an observation not seen in association with anticentromere antibody. Such reports support the role of DR5 in increasing susceptibility to severe disease. In contrast, in a study of occupationally induced scleroderma the presence of DR3 indicated increased susceptibility to severe disease. ${ }^{65}$

Typing within the class III region has also proved of interest. Thus associations have been shown with null alleles at both the C4A locus ${ }^{66}$ and the C4B locus, ${ }^{67}$ and with both loci. ${ }^{61}$ It may be that the associations with classes II and III are distinct insofar as in all the probands of Pereira et $a l^{61}$ there was either DR5 or a complement null allele. All the associations discussed above, however, even when statistically significant, are weak and the relative risks low. The immunogenetic observations are probably of limited value in explaining disease susceptibility.

\section{Environmental factors}

Unlike many of the rheumatic diseases there are considerable reports on environmental factors in the cause of scleroderma. Table 7 lists the major environmental agents implicated. In general, the female excess normally seen in scleroderma is lost when only those with a known environmental exposure are studied. Indeed scleroderma in male patients may predominantly be due to environmental exposure. ${ }^{68}$ A number of the agents listed in table 7 are derived from single case reports and the fact of exposure in a patient with scleroderma obviously does not indicate cause and effect.

\section{SILICA}

Since the description of 17 gold miners in South Africa with scleroderma, ${ }^{69}$ subsequently confirmed in other reports, ${ }^{70}{ }^{71}$ the high attributable risk of silica dust exposure for scleroderma has become apparent. Scottish stonemasons were probably the first occupational group with scleroderma to be described. ${ }^{72}$ The most important epidemiological study comes from Pittsburgh. ${ }^{73}$ of 60 men diagnosed between 1955 and 1965, 26 (43\%) were either coal miners or were in other occupations exposed to silica dust. This incidence was higher than that seen in local hospital controls (19\%) or in the fathers 
or husbands of female patients with scleroderma $(22 \%)$. It was estimated that the prevalence of scleroderma in male coal miners was twice that in the normal female population. A similar study from East Germany reported that $77 \%$ of their male patients had been exposed to silica and 39 actually had silicosis. ${ }^{68}$ They calculated that the risk of scleroderma is increased 25 times with occupational exposure and 110 times with frank silicosis. One intriguing report was of a husband and wife pair who both developed scleroderma, the husband having silica exposure and his wife perhaps becoming affected by inhaling dust from his clothes. ${ }^{74}$

\section{ORGANIC SOLVENTS}

There have been a considerable number of reports of patients developing scleroderma after exposure to organic solvents both aromatic, such as toluene, benzene, white spirit, ${ }^{75-77}$ and aliphatic, both non-halogenated and halogenated, such as perchloroethylene, ${ }^{78}$ trichloroethylene ${ }^{79-81}$; workers in dry cleaning and similar industries were particularly at risk. Vinyl chloride disease is a well recognised complication of those who clean the reactors after polymerisation. This disorder characterised by osteolysis of the phalanges, dyspnoea, fatigue, liver disease (including fibrosis and angiosarcoma), and haematological change in addition to Raynaud's phenomenon and sclerodermatous skin change is well recognised as a cause of scleroderma. ${ }^{82}$ The immunogenetics of susceptibility to scleroderma in this group of workers has already been discussed above. ${ }^{65}$ Other organic chemicals, including the so called biogenic amines, have been implicated both in epoxy resin manufacturing ${ }^{83}$ and other processes. ${ }^{84}$ Exposure to urea formaldehyde has also been implicated. ${ }^{85}$

TOXIC OIL SYNDROME

In May 1981, in Spain, there was an epidemic of a previously unrecognised multisystem disease with fever, malaise, myalgia, headaches, eosinophilia, pulmonary oedema, and rashes. An association with cooking oil was established, ${ }^{86}$ which was subsequently found to have been rapeseed oil adulterated with aniline; further cases in other parts of Spain have supported this. ${ }^{87} \mathrm{~A}$ chronic phase of the disease occurs several months after exposure, which in $30 \%$ includes a scleroderma like illness. ${ }^{88}$ The relation between toxic oil syndrome and scleroderma is still a matter of debate. There are some epidemiological similarities, including the marked excess of premenopausal women and the link with HLA-DR3. ${ }^{89}$

\section{DRUGS AND BREAST AUGMENTATION}

Table 7 lists the drugs which have been implicated in scleroderma. ${ }^{90-95}$ Exposure to most of these agents is rare apart from perhaps the appetite suppressants, and case reports are sparse. More interesting is the report of an increased risk of scleroderma in women in Japan having an augmentation mammoplasty either with paraffin or a silicone implant. ${ }^{96}$ It has been estimated that between 1955 and 197020000 women in Japan had such an operation, of whom eight developed scleroderma at an interval of 5-19 (median 14) years. This incidence is equivalent to one case per 50000 women years of follow up or an annual incidence of 20 per million, about sight times the expected incidence. Whether ihere is a connection between silica dust (see above) and silicone implant in their risk is unknown.

\section{OTHER LIFESTYLE. FACTORS}

There are few data on other lifestyle factors. Male patients in the USA did not have an excess rate of smoking before disease onset but they had a greater rate of moderate alcohol consumption than a similarly drawn control group. ${ }^{8}$ The only other finding of note is the as yet uncorroborated suggestion that there is a higher rate of prior pet ownership, particularly multiple pets (cats and dogs), in patients with scleroderma than in a peer control group. ${ }^{97}$

\section{Survival after scleroderma}

There have been a number of studies of survival in the past 50 years (tables 8 and 9). The disease definition used is unlikely to have remained constant and indeed the American College of Rheumatology (ARA) criteria were only introduced in 1980 , too late for most of the long term studies reported. The figures by Tuffanelli and Winklemann, ${ }^{98}$ based on a large series of patients seen at the Mayo Clinic
Table 8 Survival after presentation with scleroderma (Reproduced from Silman A $\mathcal{f}$. Scleroderma and survival. Ann Rheum Dis 1991; 50: 267-9.)

\begin{tabular}{|c|c|c|c|c|c|c|c|c|}
\hline \multirow{2}{*}{$\begin{array}{l}\text { First } \\
\text { author }\end{array}$} & \multirow{2}{*}{$\begin{array}{l}\text { Ref } \\
\text { No }\end{array}$} & \multirow[t]{2}{*}{ Country } & \multirow[t]{2}{*}{ Period } & \multirow{2}{*}{$\begin{array}{l}\text { Number } \\
\text { studied }\end{array}$} & \multicolumn{4}{|c|}{$\%$ Survival at year: } \\
\hline & & & & & 1 & 5 & 7 & 10 \\
\hline $\begin{array}{l}\text { Tuffanelli } \\
\text { Farmer } \\
\text { Sackner } \\
\text { Bennett } \\
\text { Medsger } \\
\text { Medsger } \\
\text { Medsger } \\
\text { Rowell } \\
\text { Barnett } \\
\text { Eason } \\
\text { Wynn } \\
\text { Bulpitt }\end{array}$ & $\begin{array}{r}98 \\
106 \\
107 \\
99 \\
108 \\
108 \\
109 \\
100 \\
110 \\
24 \\
111 \\
112\end{array}$ & $\begin{array}{l}\text { US } \\
\text { US } \\
\text { US } \\
\text { UK } \\
\text { US } \\
\text { US } \\
\text { US (men) } \\
\text { UK } \\
\text { Australia } \\
\text { New Zealand } \\
\text { US } \\
\text { US }\end{array}$ & $\begin{array}{l}1935-58 \\
1945-52 \\
1957-64 \\
1947-70 \\
1947-68 \\
1955-70 \\
1963-70\end{array}$ & $\begin{array}{r}727 \\
236 \\
65 \\
67 \\
86 \\
210 \\
358 \\
84 \\
118 \\
47 \\
64 \\
52\end{array}$ & $\begin{array}{l}68 \\
78 \\
70\end{array}$ & $\begin{array}{l}70 \\
51 \\
34 \\
73 \\
48 \\
51 \\
44\end{array}$ & $\begin{array}{l}27 \\
35 \\
35 \\
35\end{array}$ & $\begin{array}{l}74 \\
55 \\
42 \\
51\end{array}$ \\
\hline
\end{tabular}

Table 9 Survival after scleroderma by extent of skin sclerosis at presentation (results from two studies).

Reproduced from Silman A F. Scleroderma and survival. Ann Rheum Dis 1991; 50: 267-90.)

\begin{tabular}{|c|c|c|c|c|}
\hline \multirow{2}{*}{$\begin{array}{l}\text { Extent of } \\
\text { skin sclerosis }\end{array}$} & \multirow[t]{2}{*}{$n$} & \multicolumn{3}{|c|}{$\%$ Survival at years } \\
\hline & & 5 & 10 & 15 \\
\hline $\begin{array}{l}\text { Digits alone } \\
\text { Giordano et al al } \\
\text { Barnett et al }\end{array}$ & $\begin{array}{l}28 \\
86\end{array}$ & $\begin{array}{l}84 \\
79\end{array}$ & $\begin{array}{l}47 \\
75\end{array}$ & $\begin{array}{l}33 \\
43\end{array}$ \\
\hline $\begin{array}{l}\text { Intermediate } \\
\text { Giordano et al al } \\
\text { Barnett et al al } \\
\text { Truncal }\end{array}$ & $\begin{array}{l}25 \\
66\end{array}$ & $\begin{array}{l}75 \\
77\end{array}$ & $\begin{array}{l}22 \\
61\end{array}$ & $\begin{array}{l}10 \\
48\end{array}$ \\
\hline $\begin{array}{l}\text { Giordano et al al } \\
\text { Barnett et al al }\end{array}$ & $\begin{array}{l}37 \\
25\end{array}$ & $\begin{array}{l}50 \\
48\end{array}$ & $\begin{array}{l}26 \\
22\end{array}$ & 17 \\
\hline
\end{tabular}


between 1935 and 1958, are likely to be overestimates given the relatively large number of subjects for whom follow up data were unavailable. The data from Farmer et $a l^{106}$ are also derived fiom the same group, but a more restricted sample (those diagnosed between 1945 and 1952), and interestingly show a lower five year survival rate of around $50 \%$. The surprising aspect about the data from the numerous studies presented in the table is the relative consistency of survival reports between centres and countries despite the relatively long time period covered by these studies. There have only been two studies from the United Kingdom, ${ }^{99}{ }^{100}$ both on relatively small numbers of cases, but both showing a higher survival than results from other centres would suggest. In all studies survival decreases with increasing follow up, which is not solely a feature of increasing age. ${ }^{13}$ The average age at the start of follow up in these series is between 40 and $\mathbf{5 0}$ and the general population survival rates over a 10 year period in this age group would be expected to be high. The increased mortality is relatively linear over time, and in those studies with 15 or more years of follow up ${ }^{19} 101102$ shows no signs of reaching a plateau. Although anecdotally there are clinical observations of the disease running a benign course for many years, the conclusion from studying groups is that even prolonged survival does not protect against an increased risk of death.

\section{CANCER RISK}

There have been some interesting suggestions of specific cancer risks with scleroderma. One report of an unexpected cluster of cases of breast cancer in women with scleroderma ${ }^{103}$ was followed by a formal epidemiological study that could not confirm this excess of breast cancer but did suggest a temporal relation between the onset of the two diseases in some women. ${ }^{104}$ More relevant in that study was the increased incidence of lung cancer in patients with scleroderma. This seems to be independent of cigarette smoking but related to the presence of pulmonary fibrosis, ${ }^{105}$ and is perhaps not surprising given the association of lung cancer with pulmonary fibrosis from occupational causes. Thus it is perhaps likely that part of the increased mortality from scleroderma is not directly attributable to the scleroderma associated pathological changes, though the exact magnitude of any increased risk in 'unrelated' deaths is unknown.

1 Subcommittee for scleroderma criteria of the American Rheumatism Association Diagnostic and Therapeutic cation of systemic sclerosis (scleroderma). Arthritis Rheum 1980; 23: 581-90.

2 Wigley R D, Borman B. Medical geography and the aetiology of the rare connective tissue diseases in New aetiology of the rare connective tissue disea
Zealand. Soc Sci Med 1980; 14D: 175-83.

3 Tan P L J, Wigley R D, Borman B. Clinical criteria for systemic sclerosis. Arthritis Rheum 1981; 24: 1589-90.

4 Jannssens $X$, Herman L, Mielants H, Verbruggen G, Veys $E$ M. Disease manifestations of progressive systemic sclerosis: sensitivity and specificity. Clin Rheumatol 1987; 6: $532-8$.

5 Masi A T, D'Angleo W A. Epidemiology of fatal systemic sclerosis (diffuse scleroderma). Ann Intern Med 1967; 66:
870-5.
6 Cobb S. The frequency of rheumatic diseases. Cambridge: Harvard University Press, 1971

7 Hochberg M C, Lopez-Acuna D, Gittlesohn A M. Mortality from systemic sclerosis (scleroderma) in the United States, 1969-85. In: Black C M, Myers A R, eds. Systemic sclerosis (scleroderma) New York: Gower, 1985: 61-9.

8 Medsger T A, Masi A T. The epidemiology of systemic sclerosis (scleroderma) among male US veterans. $\mathcal{f}$ Sclerosis (scleroderma) amon

9 Silman A J. Mortality from scleroderma in England and Wales 1968-1985. Ann Rheum Dis 1991; 50: 95-6.

10 Steen V, Conte C, Santoro D, et al. Twenty year incidence survey of systemic sclerosis [abstract]. Arthritis Rheum 1988; 31 (suppl 14): 557.

11 Kurland L T, Hauser W A, Ferguson R H, Holley K E. Epidemiologic features of diffuse connective tissue disorders in Rochester Minn, 1951 through 1967 with specia reference to systemic lupus erythematosus. Mayo Clin Proc 1969; 44: 649-63.

12 Michet C J, McKenna C H, Elveback L R, Kaslow R A, Kurland L T. Epidemiology of systemic lupus erythematosus and other connective tissue disease in Rochester Minnesota, 1950 through 1979. Mayo Clin Proc 1985; 60: 105-13.

12a Bosmansky $K$, Zitnan $D$, Urbanek $T$, Svec U. Incidence of diffuse disorders of the connective tissue with special reference to systemic lupus erythematosus in a selected district in the years 1961-69. Fysiatr Reumatol Vestn 1971 49: 267-72.

12b Asboe-Hansen G. Epidemiology of systemic sclerosis in Denmark. In: Black C M, Myers A R, eds. Systemic sclerosis (scleroderma). New York: Gower, 1985: 78.

12c Haustein U F, Ziegler V, Zschunke E, et al. Progressive systemic sclerosis with silicosis in the German Democratic Republic. In: Black C M, Myers A R, eds. Systemic sclerosis (scleroderma). New York: Gower, 1985: 138-142.

13 Medsger T A, Masi A T. Epidemiology of systemic sclerosis (scleroderma). Ann Intern Med 1971; 74: 714-21.

14 Silman A J, Jannini S, Symmons D, Bacon P. An epidemiological study of scleroderma in the West Midlands. Br 7 Rheumatol 1988; 27: 286-90.

15 Ansell B M, Nasseh G A, Bywaters E G L. Scleroderma in childhood. Ann Rheum Dis 1976; 35: 189-97.

16 Burge S M, Ryan T J, Dawber R P R. Juvenile onset systemic sclerosis. $f R$ Soc Med 1984; 77: 793-4.

17 Dalziel J A, Wilcox G K. Progressive systemic sclerosis in the elderly. Postgrad Med f 1979; 55: 192-3.

18 Anonymous. Systemic sclerosis in old age (editorial). $B M \mathcal{Y}$ 1979; ii: 1313-4.

19 Medsger T A, Jr. Epidemiology of progressive systemic sclerosis. In: Black C M, Myers A R, eds. Systemic sclerosis (scleroderma). New York: Gower, 1985: 53-9.

20 Maricq H R, Weinrich M C, Keil J E, LeRoy E C. Prevalence of Raynaud's phenomenon in the general population. I Chronic Dis 1986; 39: 423-7.

21 Shinkai $H$. Epidemiology of progressive systemic sclerosis in Japan. In: Black C M, Myers A R, eds. Systemic sclerosis (scleroderma). New York: Gower, 1985: 78.

22 Somorin A O, Mordi V I N. Connective tissue disease in Nigeria with emphasis on scleroderma. Cent Afr $\mathcal{F} \mathrm{Med}$ 1980; 26: 59-63.

23 de Kasep G I, Alarcon-Segovia D. Preliminary epidemiologic data on progressive systemic sclerosis. In: Black $C M$, Myers A R, eds. Systemic sclerosis (scleroderma). New York: Gower, 1985: 70-1.

24. Eason R J, Tan P L, Gow P J. Progressive systemic sclerosis in Auckland: a ten year review with emphasis on
prognostic features. Aust $N Z \mathcal{F}$ Med 1981; 11: 657-62.

25 Barnett A J. Epidemiology of systemic sclerosis (scleroderma) in Australia. In: Black C M, Myers A R, eds. derma) in Australia. In: Black C M, Myers A R, eds. Systemic Sclerosis (scleroderma). New York: Gower, 1985: 82-3.

26 Silman A J, Howard Y, Hicklin A J, Black C M Geographical clustering of scleroderma in South and West London. Br F Rheumatol 1990; 29: 92-6.

27 Freni-Titulaer L W J, Kelley D B, Grow A G, et al. Connective tissue disease in south eastern Georgia: a casecontrol study. Am f Epidemiol 1989; 130: 404-9.

28 Giordano M, Valentini G, Vatti M, Tirri G, Gualdieri L, Lupoli S. Epidemiology of systemic sclerosis in Italy. Connective Tissue Disease 1984; 3: 16.

29 Serup J, Hagdrup H K. Age at menopause of females with systemic sclerosis. Acta Derm Venereol (Stockh) 1983; 63: $71-3$

30 Ballou S P, Morley J J, Kushner I. Pregnancy and systemic sclerosis. Arthritis Rheum 1984; 27: 295-8.

31 Silman A J, Black C M. Increased incidence of spontaneous abortion and infertility in women with scleroderma before disease onset: a controlled study. Ann Rheum Dis 1988; 47: 441-4.

32 Giordano M, Valentini G, Lupoli S, Giordano A. Pregnancy and svstemic sclersosis. Arthritis Rheum 1985; 28: 237-8.

33 Steen V D, Conte C, Day N, Ramsey-Goldman R, Medsger T A. Pregnancy in women with scleroderma. Arthritis Rheum 1989; 32: 151-7.

33a McHugh N H, Reilly P A, McHugh L A. Pregnancy outcome and autoantibodies in connective tissue disease. f Rheumatol 1989; 16: 42-6.

34 Slate W G, Graham A R. Scleroderma and pregnancy. Am $\mathcal{J}$ Obstet Gynecol 1968; 101: 335-41.

35 Rees R B, Bennett J. Localised scleroderma in father and daughter. Arch Dermatol 1953; 68: 360.

36 Orabona M L, Albano O. Progressive systemic sclerosis (or 
visceral scleroderma). Review of literature and report of cases. Acta Med Scand 1958; 160 (suppl 333): 1-170.

37 Blanchard R D, Speed E M. Scleroderma: peridontal me 1965; 3: 77-80.

38 McAndrew G M, Barnes E G. Familial scleroderma. Ann Phys Med 1965; 8: 128-31.

39 Burge K M, Perry H O, Stickler G B. Familial scleroderma. Arch Dermatol 1969; 99: 681-7.

40 Rendall J R, McKenzie A W. Familial scleroderma. Br f Dermatol 1974; 91: 517-22.

41 Greger R E. Familial progressive systemic scleroderma. Arch Dermatol 1975; 111: 81-5.

42 Mund D J, Greenwald R A. The CREST syndrome variant of scleroderma in a mother-daughter pair. $\mathcal{F}$ Rheumatol 1978; 5: 307-10.

43 Sheldon W B, Lurie D P, Maricq H R, et al. Three siblings with scleroderma (systemic sclerosis) and two with with scleroderma (systemic sclerosis) and two with
Raynaud's phenomenon from a single kindred. Arthritis Raynaud's phenomenon

44 Soppi E, Lehtonen A, Toivanen A. Familial progressive systemic sclerosis (scleroderma): immunological analysis of two patients and six siblings from a single kindred. Clin Exp Immunol 1982; 50: 275-82.

45 McGregor A R, Watson A, Yunis E, et al. Familial clustering of scleroderma spectrum disease. $A m \mathcal{F} \mathrm{Med}$ 1988; 84: 1023-32.

46 Tuffanelli D L. Scleroderma, immunological and genetic disease in three families. Dermatologica 1969; 138: 93-104.

47 Emerit I, Mousset E, Feingold J. Chromosomal breakage and scleroderma: studies in family members. $\mathcal{f} \mathrm{Lab} \mathrm{Clin}$ Med 1976; 88: 81-6.

48 Maddison P J, Skinner R P, Pereira R S, et al. Antinuclear antibodies in the relatives and spouses of patients with systemic sclerosis. Ann Rheum Dis 1986; 45: 793-9.

49 Guseva N G, Folomeeva O M, Oskilko T G. Familial systemic sclerosis: a follow up study of concordant monozygotic twins. Ter Arkh 1981; 53: 43-7

50 Dustoor M M, McInerney M M, Mazanec D J, Cathcart M K. Abnormal lymphocyte function in scleroderma: a study of identical twins. Clin Immunol Immunopathol 1987; 44: 20-30.

51 Rabin B S, Rodnan G P, Bassion S, Gill T J. HLA antigens in progressive systemic sclerosis (scleroderma). Arthritis Rheum 1975; 18: 381-2

52 Hughes $\mathrm{R}$, Gelsthorpe $\mathrm{K}$, Doughty $\mathrm{R} W$, et al. The association of HLA-B8 with visceral disease in systemic sclerosis. Clin Exp Immunol 1978; 31: 351-6.

53 Birnbaum N S, Rodnan G P, Rabin B S, Bassion S. Histocompatibility antigens in progressive systemic sclerosis (scleroderma). F Rheumatol 1977; 4: 425-8.

54 Kallenberg G C M, Van der Voort-Beelen J M, D'Amaro J, The T H. Scleroderma, increased frequency of B8/DR 3 in scleroderma and association of the haplotype with impaired cellular immune response. Clin Exp Immunol 1981; 43: 478-85

55 Lynch C J, Singh G, Whiteside T L, et al. Histocompatibility antigens in progressive systemic sclerosis (PSS scieroderma). f Clin Immunol 1982; 2: 314-8.

56 Gladman D D, Keystone E C, Baron M, Lee P, Cane D, Mervert H. Increased frequency of HLA-DR5 in scleroderma. Arthritis Rheum 1981; 24: 854-6.

57 Black C M, Welsh K I, Maddison P J, et al. HLA antigens, autoantibodies and clinical subsets in scleroderma. $\mathrm{Br} \mathcal{F}$ Rheumatol 1984; 23: 267-71.

58 Barnett A J, Tait B D, Barnett M A, Toh B H. T ymphocyte subset abnormalities and HLA antigens in scleroderma. Clin Exp Immunol 1989; 76: 24-9.

59 Kondo H, Yoshii M, Kashiwazaki S, Kashiwagi N. Histocompatibility antigens in progressive systemic sclerosis. In: Black C M, Myers A R, eds. Systemic sclerosis (scleroderma). New York: Gower, 1985: 97-102.

59a Livingston J Z, Scott T E, Wigley F M, et al. Systemic sclerosis (scleroderma): clinical, genetic and serologic sclerosis (scleroderma): clinical, genet

60 Welsh K I, Black C M. Environmental and genetic factors in scleroderma. In: Jayson M I V, Black C M, eds. Systemic sclerosis: scleroderma. London: Wiley, 1988: 33-48.

61 Pereira S, Black C M, Welsh K, et al. Autoantibodies and immunogenetics in 30 patients with systemic sclerosis. $\mathcal{J}$ Rheumatol 1987; 14: 760-5.

62 Whiteside T L, Medsger T A, Rodnan G P. HLA-DR antigen in progressive sytemic sclerosis (scleroderma). 7 Rheumatol 1983; 10: 128-31.

63 Alarcon G S, McCarty G A, Lanyon P, et al. Scleroderma: $\mathrm{DR}$ antigens, autoantibodies and clinical manifestations. Clin Exp Rheumatol 1987; 5: 317-21.

64 Genth E, Mierau R, Genetzky P, et al., Immunogenetic associations of scleroderma-related antinuclear antibodies. Arthritis Rheum 1990; 33: 657-65.
associations of scleroderma-related

65 Black C M, Welsh K I, Walker A E, et al. Genetic susceptibility to scleroderma-like syndrome induced by susceptibility to scleroderma-like synd
vinyl chloride. Lancet 1983; i: 53-5.

66 Briggs D, Welsh K I, Pereira R S, Black, C M. A strong association between null alleles at the CAA locus in the major histocompatibility complex and systemic sclerosis. major histocompatibility complex

67 Mollenhauer E, Schmidt R, Heinrichs M, Rittner C. Scleroderma: possible significance of silent alleles at the C4B locus. Arthritis Rheum 1984; 27: 711-2.

68 Haustein U F, Ziegler V. Environmentally induced systemic sclerosis-like disorders. Int f Dermatol 1985; 24: 147-51.

69 Erasmus L D. Scleroderma in gold miners on the Witz Witwatersrand with particular reference to pulmonary
manifestations. S Afr $\mathcal{F}$ Lab Clin Med 1957; 3: 209-31.
70 Bernstein R, Prinsloo I, Zwi S, et al. Chromosomal aberrations in occupational-ascociated progressive systemic sclerosis. S Afr Med f 1980; 58: 235-7.

71 Cowie R L. Silica dust exposed mine workers with scleroderma (systemic sclerosis). Chest 1987; 92: 260.

72 Bramwell B. Diffuse scleroderma: its frequency, its occurrence in stone masons, its treatment by fibrolysinelevations of temperature due to fibrolysin injections. Edinburgh Med f 1914: 12: 387-401.

73 Rodnan G P, Benedek T G, Medsger T A, Cammaratta R J. The association of progressive systemic sclerosis (scleroderma) with coal miners pneumoconiosis and other forms of silicosis. Ann Intern Med 1967; 66: 323-34.

74 Christy W C, Rodnan G P. Conjugal progressive systemic sclerosis (scleroderma): report of the disease in husband and wife. Arthritis Rheum 1984; 27: 1180-2.

75 Walder B K. Solvents and scleroderma. Lancet 1965; ii: 436-7.

76 Walder B K. Do solvents cause scleroderma? Int Soc Trop Dermatol 1983; 22: 157-8.

77 Czirjak L, Katalin D, Schlammadinger J, Suranyi $\mathbf{P}$, Tamasi L, Szegedi G Y. Progressive systemic sclerosis occurring in patients exposed to chemicals. Int 7 Dermatol 1987; 26: 374

78 Sparrow G P. A connective tissue disorder similar to vinyl chloride disease in a patient exposed to perchlorethylene. Clin Dermatol 1977; 2: 17-22.

79 Reinl W. Sklerodermie durch Trichlorethylen-Einwirkung? (trans). Bull Hygiene 1957; 32: 678-9.

80 Saihan E M, Burton J L, Heaton K W. A new syndrome with pigmentation, scleroderma, gynaecomastia, with pigmentation, scleroderma, gynaecomastia, 1978; 99: 437-40.

81 Lockey J E, Kelley C R, Cannon G W, et al. Progressive systemic sclerosis associated with exposure to trichloroethylene. F Occup Med 1987; 29: 493-6.

82 Veltman C, Lange C E, Juhe S, Stein G, Bachner V. Clinical manifestations and course of vinyl chloride disease. Ann NY Acad Sci 1975; 246: 6-17.

83 Yamakage A, Ishikawa $\mathrm{H}$, Saito $\mathrm{Y}$, et al. Occupational scleroderma-like disorders occurring in men engaged in the polymerization of epoxy resins. Dermatologica 1980;

84 Owens G R, Medsger T A. Systemic scleroderma secondary to occupational exposure. Am 7 Med 1988; 85: 114-6.

85 Rush P J, Chaiton A. Scleroderma, renal failure and death associated with exposure to urea formaldehyde foam insulation. $\mathcal{F}$ Rheumatol 1986; 13: 475.

86 Tabuenca J M. Toxic-allergic syndrome caused by ingestion of rapeseed oil denatured with aniline. Lancet 1981; ii: 567-8.

87 Pesada M, Castro M, Filbourne E M, et al. Toxic-oil syndrome: case reports associated with the ITH oil refinery in Sevilla. Food Chem Toxicol 1989; 25: 87-90.

88 Kilbourne E M, Rigau-Perez J G, Heath C W, et al. Clinical epidemiology of toxic-oil syndrome manifestations of a new illness. N Engl f Med 1983; 309: 1408-14.

89 Alonzo-Ruiz, Zea-Mendoza A, Salazar-Vallinas J Rocamore-Ripoll A. Toxic oil syndrome: a syndrome with features overlapping those of various forms of scleroderma. Semin Arthritis Rheum 1986; 15: 200-12.

90 Finch W R, Rodnan G P, Buckingham R B, Prince R K, Winkelstein A. Bleomycin-induced scleroderma. 7 Rheumatol 1980; 7: 651-9.

91 Palestine R F, Millons J L, Spigel G T, et al. Skin manifestations of pentazocine abuse. 7 Am Acad Dermatol $1980 ; 2$ : 47-55.

92 Sternberg E M, Van Woert M H, Young S N, et al. Development of a scleroderma-like illness during therapy with L-5-hydroxytryptophan and carbidopa. $N$ Engl f Med 1980; 303: 782-7.

93 Trozak D J, Gould N M. Cocaine abuse and connective tissue disease. F Am Acad Dermatol 1984; 10: 525.

94 Tomlinson I W, Jayson M I. Systemic sclerosis after therapy with appetite suppresssants. F Rheumatol 1984; 11 : 254 .

95 Aeschlimann A, de Truchis P, Kahn M F. Scleroderma after therapy with appetite suppressants. Scand $\mathcal{J}$

96 Kumagai Y, Shiokawa Y, Medsger T A, Rodnan G P. Clinical spectrum of connective tissue disease after cosmetic surgery. Arthritis Rheum 1984; 27: 1-12.

97 Silman A J, Jones S. Pet ownership: a possible risk factor for scleroderma. Br f R heumatol 1990; 29: 494.

98 Tuffanelli D L, Winklemann R K. Systemic scleroderma: clinical study of 727 cases. Arch Dermatol 1961; 84: $359-71$.

99 Bennett R, Bluestone R, Holt P J L, Bywaters E G L. Survival in scleroderma. Ann Rheum Dis 1971; 30: 581-8. 100 Rowell N R. The prognosis of systemic sclerosis. $B r \dot{f}$ Dermatol 1976; 95: 57-60.

101 Giordano M, Valentini G, Migliaresi S, Picillo U, Vatti M. Different antibody patterns and different prognoses in scleroderma patients with various extents of skin sclerosis. f Rheumatol.1986; 13: 911-6.

102 Barnett A J, Miller M H, Littlejohn G O. A survival study of patients with scleroderma diagnosed over 30 years. $\mathcal{f}$ Rheumatol 1988; 15: 276-7.

103 Lee P, Alderdice C, Wilkinson S, Keystone E C, Urowitz $M$ B. Malignancy in progressive systemic sclerosis association with breast carcinoma. I Rheumatol 1983; 10:

104 Roumm A D, Medsger T A. Cancer and systemic sclerosis. 
105 Peters-Golden $M$, Wise R A, Hochberg M, Stevens $M$ B, Wigley $F$ M. Incidence of lung cancer in sytemic sclerosis: 7 Rheumatol 1985; 12: 1136-9.

106 Farmer R G, Gifford R W, Hines E A. Prognostic significance of Raynaud's phenomenon and other clinica characteristics of systemic scleroderma. Circulation 1960;

107 Sackner M A. Scleroderma, Grune \& Stratton 1966, New York. In: Jayson M I V, Black C M, eds. Systemic sclerosis: scleroderma. London: Wiley, 1988: 7-31.

108 Medsger T A, Rodnan G P, Robinson H. Survival with systemic sclerosis (scleroderma). A life-table analysis of clinical and demographic factors in 309 patients. Ann Intern Med 1971; 75: 369-76.
109 Medsger T A, Masi A T. Survival with scleroderma. II: A life-table analysis of clinical and demographic factors in 358 male US veteran patients. $f$ Chronic Dis 1973; 26: $647-60$.

110 Barnett A J. Scleroderma (progressive systemic sclerosis): progress and course based on a personal series of 118 progress and course based on a personal series of 118
cases. Med $\mathcal{F}$ A ust 1978; 2: 129-34.

111 Wynn J, Fineberg N, Metzer L, et al. Prediction of survival in progressive systemic sclerosis by multivariate analysis of clinical features. Am

112 Bulpitt K, Clements P, Lachenbruch P, Paulus H. Prospective study of early systemic sclerosis: outcome and prognostic indicators. Arthritis Rheum 1990; 33: (suppl) R6. 